\title{
The Effect of Coho Spawning on the Benthic Invertebrates of the Platte River, Benzie County, Michigan
}

\author{
Stephen G. Hildebrand \\ Department of Wildlife and Fisheries \\ The University of Michigan, Ann Arbor, Michigan 48104
}

\begin{abstract}
This study was undertaken to determine what effects a spawning run of coho salmon would have on the benthos of the Platte River, Benzie County, Michigan. It was hypothesized that the physical disruption of the substrate, by spawning salmon, would reduce the density of benthos by dislodging the organisms and causing their downstream displacement.

Estimates of density of benthic invertebrates were made in two control sections (salmon excluded) and in one experimental section (salmon having free access) in May and August 1967 prior to coho spawning run, and in December 1967 and May 1968 after the run. Coho spawning activity in the fall of 1967 disturbed the bottom materials. The densities of 12 taxa, as well as the total number and total weight of organisms per square foot, decreased significantly in samples collected in December after disruption. The decrease in total number of organisms per square foot in the experimental section as compared to the controls was 270.5 ; the decrease in weight in the experimental section was 1.97 grams. This is a percent decrease in the experimental section relative to the controls of $66 \%$ for total number and $78 \%$ for total weight. In May 1968, the number of organisms per square foot was still significantly lower in the experimental section ( 57.4 per square foot), but weight of organisms per square foot was not. The percent decrease in the experimental section relative to the controls for total number was $39 \%$. Three of twelve taxa, whose density was reduced in the fall of 1967 , were still lower in May 1968. Complete recovery of benthos was not observed in the 5 -month period from December to May.
\end{abstract}

\section{INTRODUCTION}

The introduction of an exotic organism into a new geographic area usually has important effects upon the native species. The coho salmon, Oncorhynchus kisutch (Walbaum), was introduced into Lake Michigan and Lake Superior in the spring of 1966. By the fall of 1966 there were indications that the coho would thrive in Lake Michigan. At this time studies were planned to evaluate its relation with established species. The following study was undertaken to determine what effects a spawning run of coho salmon would have on the benthic invertebrates in a stream.

One of the three Michigan streams that received introductions of coho was the Platte River, Benzie County. The Department of Natural Resources released 264,596 yearlings into the stream in March. The smolts soon moved into Lake Michigan. It was reasoned that if substantial numbers of salmon survived and returned to the same stream to spawn, they could seriously disturb the substrate and its fauna. A coho digs a large redd. The mean area of 65 coho redds examined in the Toutle River, a tributary of the Columbia
River, was 3.4 square yards (Burner, 1951). It seemed likely that extensive disruption of the stream substrate would displace many benthic invertebrates, and cause considerable mortality in others, and thereby reduce the food supply of the stream salmonids.

\section{STUDY AREA}

The Platte River rises in Grand Traverse County, Michigan, and flows west, across Benzie County, for approximately 25 miles into Lake Michigan. The soil of the area is mostly sand. The stream has a fairly high gradient and stable flow, and its banks are wooded mainly with cedar, hemlock, and aspens. Except near the mouth and in the vicinity of lakes near the headwaters, numerous springs and groundwater seepage maintain temperatures suitable for salmonid fishes throughout the year.

The study area consisted of three 1-mile sections of the stream in Benzie County ( $T$. 26N., R. 14W., Sec. 12 and 13, and T. 26N., R. $13 W$., Sec. 5, 6, and 7), in the immediate vicinity of the Platte River Trout Rearing Station. Two of the sections were designated as 
TABle 1.-Physical characteristics of the test sections of the Platte River, Benzie County, Michigan

\begin{tabular}{|c|c|c|c|c|c|c|}
\hline \multirow[b]{2}{*}{ Section } & \multirow{2}{*}{$\begin{array}{c}\text { Mean } \\
\text { depth } \\
\text { (inches) }\end{array}$} & \multirow{2}{*}{$\begin{array}{l}\text { Mean } \\
\text { width } \\
\text { (feet) }\end{array}$} & \multirow{2}{*}{$\begin{array}{c}\text { Mean } \\
\text { area } \\
\text { (square feet) }\end{array}$} & \multicolumn{3}{|c|}{ Estimated percentage bottom types } \\
\hline & & & & Gravel & Sand & Silt-sand \\
\hline \multicolumn{7}{|l|}{ Control } \\
\hline $\begin{array}{l}\text { Upper } \\
\text { Lower }\end{array}$ & $\begin{array}{r}9.6 \\
11.2\end{array}$ & $\begin{array}{l}50.8 \\
43.7\end{array}$ & $\begin{array}{l}268,224 \\
230,736\end{array}$ & $\begin{array}{l}78.3 \\
63.3\end{array}$ & $\begin{array}{l}13.3 \\
15.0\end{array}$ & $\begin{array}{r}8.4 \\
21.6\end{array}$ \\
\hline Experimental & 14.1 & 43.9 & 231,792 & 66.6 & 21.6 & 11.6 \\
\hline
\end{tabular}

control areas, and the third was designated as experimental. Adult migrant salmon had access to the latter section, but were excluded from control areas by a weir used for spawn taking. Table 1 shows some physical characteristics of the test sections.

The fish population in the study area was composed mainly of brown trout (Salmo trutta) and rainbow trout (Salmo gairdneri). Brook trout (Salvelinus fontinalis) were rare. Some juvenile coho saImon have escaped into the river from the rearing ponds, and naturally produced coho have been present in the experimental section since the spring of 1968 . Other resident fishes of importance were the blacknose dace (Rhinichthys atratulus) and the mottled sculpin (Cottus bairdi).

\section{METHODS}

Twenty 1-square-foot bottom samples were taken at random in each stream section during each sampling period. There were two sampling periods before salmon spawning (May and August, 1967) and two periods after spawning (December 1967, May 1968). Prior to the May 1967 sampling, each mile section was marked off in 300-foot intervals. The location of the sampling sites was determined during each sampling period from tables of random numbers in the following manner. All 20 length coordinates for each stream section were selected from a range of numbers from 0 to 5,280 ; width coordinates were selected at the time of sampling from a range extending from 0 to the stream width measurement (in feet) at the location of each length coordinate.

For each sampling site, substrate type was classified as either gravel, sand, or silt-sand. The consistency of the types was as follows:

Gravel-an estimated $30-90 \%$ of the ma- terial being gravel $(2-75 \mathrm{~mm}$ in diameter), the balance being sand.

Sand--loosely packed particles, little gravel. Silt-sand-roughly a 50-50 mixture of loosely packed silt and fine sand.

Bottom samples were collected with a modified Hess sampler similar to the one described by Waters and Knapp (1961). Samples were sieved through a No. 30 screen. Benthic or. ganisms were either removed from samples while they were still alive, or were preserved in $10 \%$ formalin and the animals removed at a later date using a sugar flotation technique similar to that described by Anderson (1959). Both methods of sorting appeared to be equally efficient. The organisms removed from samples were preserved in $70 \%$ alcohol.

With the exception of Nematoda and Oligochaeta, all aquatic invertebrates were identified to family, genus, or species. Counts were made of each taxon and the total number of individuals were tallied for each sample. Average weights of each taxon were calculated for each stream section and each sampling date in the following manner. A known number of individuals of each taxon were centrifuged at $1,000 \mathrm{rpm}$ for 45 seconds to remove excess moisture, and were then weighed on an analytical balance. Trichoptera, except for the genus Helicopsyche, were weighed without cases. This weight in grams, divided by the number weighed, gave the average weight of individuals of each taxon. Total sample weights were calculated for each sample by multiplying counts for each taxon by its average weight, and summing these products.

Only samples taken in gravel substrate were analyzed statistically because observations of Shapovalov and Taft (1954) suggest that coho confine most of their spawning to gravel. An equal number of samples taken in gravel 
within each stream section on each sampling date were desired for analysis. Since sampling sites were selected at random, the sets of 20 samples collected in each stream section on each sampling date seldom had the same number of samples taken in gravel. The smallest number of gravel samples in a set was 14 . For sample sets that contained more than 14 samples of gravel, the appropriate number of samples to be discarded were selected randomly and removed so that each set contained only 14 samples. A total of 168 samples, 14 from each of three stream sections for four sampling periods were analyzed statistically.

The counts and weight data were transformed to $\log _{e} x+1$. A factorial two-way analysis of variance was performed on the transformed data. Classification was by stream section and sampling date. A separate analysis of variance was run for each taxon, total num. ber per sample, and total sample weight.

The two hypotheses given below were tested for the total number of organisms, the total weight of organisms, and for the number in each taxon except those taxa not present in the stream in December 1967. Tests were not performed on Helicopsyche borealis because there was reason to believe that many individuals of this species were missed in the sorting process due to its heavy case. A single degree of freedom orthogonal comparison was employed as described in Steel and Torrie (1960, p. 213). The hypotheses regarding the density of benthic invertebrates were:

(1) The difference in density between experimental and control sections in December 1967, was greater than differences between these sections during other sampling periods. Two assumptions were made. First, all conditions affecting the density of benthic invertebrates in experimental and control sections were the same except for the presence of salmon in the experimental section. Second, that the adult salmon did not feed on benthos in the river. With these assumptions, a significant decrease in benthos density in December could be attributed to salmon spawning activity.
TABLE 2.-Numerical abundance of taxonomic groups, expressed as percentages of the total number of organisms, in 190 square-foot samples of gravel substrate collected in May, August, December 1967, and May 1968

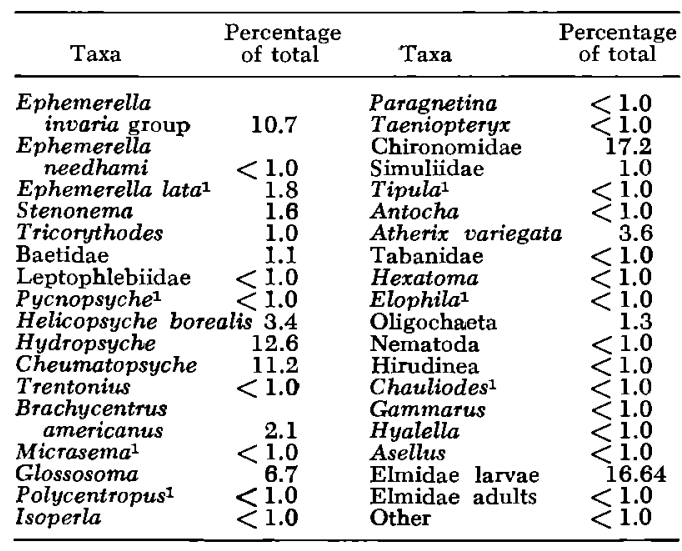

1 Indicates taxa not found in the experimental section, or not found in experimental or control sections in December.

(2) The difference between experimental and control sections in May 1968, was greater than differences between these sections in May 1967. The same assumptions are invoked here as in hy. pothesis (1). A significant difference under this hypothesis provides evidence that the effect of fall spawning on the density of benthos persists for at least 5 months.

One-tailed F tests were employed for both hypotheses because the only meaningful result in terms of this experiment was a reduction in benthos in the experimental section as compared to the controls. All changes in benthos discussed below are verified in terms of these two hypotheses.

\section{RESULTS AND DISCUSSION}

Thirty-six taxonomic groups of aquatic invertebrates were identified from 190 samples from gravel substrate in the three stream sections during the four sampling periods. Taxa that predominated numerically were Atherix variegata and other Diptera of the families Chironomidae and Simuliidae; Coleoptera of the family Elmidae; Brachycentrus americanus, Helicopsyche borealis and other Tri- 


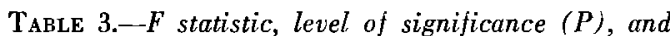
difference in density between the experimental and the mean for the two control sections in December 1967, for taxa affected by salmon spawning activity

\begin{tabular}{|c|c|c|c|}
\hline Taxa & F & $P$ & $\begin{array}{l}\text { Difference } \\
\text { in density } \\
\text { (number } / \mathrm{ft}^{2} \text { ) }\end{array}$ \\
\hline $\begin{array}{l}\text { Ephemerella invaria group } \\
\text { Stenonema } \\
\text { Baetidae } \\
\text { Leptophlebiidae } \\
\text { Hydropsyche } \\
\text { Cheumatopsyche } \\
\text { Brachycentrus americanus } \\
\text { Chironomidae } \\
\text { Antocha } \\
\text { Oligochaeta } \\
\text { Hyalella } \\
\text { Elmidae adult }\end{array}$ & $\begin{array}{r}26.60 \\
21.22 \\
9.19 \\
20.79 \\
48.24 \\
21.53 \\
11.57 \\
2.93 \\
12.44 \\
3.28 \\
3.37 \\
5.69\end{array}$ & $\begin{array}{l}<.01 \\
\sum .01 \\
\sum .01 \\
\leq .01 \\
\leq .01 \\
\leq .01 \\
\sum .01 \\
\sum .05 \\
<.01 \\
\sum .05 \\
\sum .05 \\
<.01\end{array}$ & $\begin{array}{r}-37.15 \\
-7.06 \\
-1.12 \\
-1.06 \\
-51.50 \\
-32.95 \\
-0.38 \\
-21.35 \\
-2.08 \\
-2.17 \\
-0.65 \\
-0.71\end{array}$ \\
\hline Total number & 14.91 & $<.01$ & -270.50 \\
\hline Total weight & 27.68 & $<.01$ & $\begin{array}{l}-1.97 \\
\text { grams }\end{array}$ \\
\hline
\end{tabular}

choptera of the genera Hydropsyche, Cheumatopsyche, and Glossosoma; Ephemerella, Stenonema, Tricorythodes, and other Ephemeroptera of the family Baetidae; and aquatic Oligochaeta. These taxa contained $92 \%$ of the total number of individuals collected in the above samples (Table 2). The greatest density of all categories of organisms combined was 443 animals per square foot. This was encountered in the upper control section in December 1967. Seven of the thirty-six taxa recognized in this study were not present in the experimental or control sections in December 1967. These were not analyzed further (Table 2).

The first substantial numbers of spawning salmon arrived at the weir on the Platte River (about 10 miles above the mouth) on 9 October 1967. Runs continued from this date through January of 1968. A total of 51,574 adult salmon were counted in the fall of $1967 .{ }^{1}$

There were large concentrations of salmon in the experimental section in October and November after the initial run. On 24 October there were an estimated 10,000 coho in this section (Clarence M. Taube, unpublished data). Assuming half of the fish were females, and a mean redd size of 3.4 square yards, these salmon could have disturbed 17,000 square yards of gravel during spawning. I estimated the area of gravel within the experi-

\footnotetext{
${ }^{1}$ Coopes, Gary F. 1968. 1967 fall salmon report Region II, District 6. Michigan Department of Natural Resources, 12 p. (mimeo.)
}

TABLE 4.-F statistic, level of significance $(P)$, and difference in density between the experimental and the mean for the two control sections in May 1968, for taxa affected by salmon spawning activity in the fall of 1967

\begin{tabular}{|c|c|c|c|}
\hline Taxa & $\mathbf{F}$ & $\mathbf{P}$ & $\begin{array}{c}\text { Difference } \\
\text { in density } \\
\left(\text { number } / \mathrm{ft}^{2}\right)\end{array}$ \\
\hline $\begin{array}{l}\text { Stenonema } \\
\text { Leptophlebiidae } \\
\text { Brachycentrus americanus } \\
\text { Hexatoma }\end{array}$ & $\begin{array}{r}10.04 \\
11.25 \\
24.04 \\
4.21\end{array}$ & $\begin{array}{l}<.01 \\
<.01 \\
<.01 \\
.01\end{array}$ & $\begin{array}{l}-2.85 \\
-0.32 \\
-1.53 \\
-1.08\end{array}$ \\
\hline Total number & 4.15 & $<.01$ & -57.40 \\
\hline
\end{tabular}

mental section to be 18,000 square yards. However, only a portion of these coho spawned in the experimental section; many of them were subsequently captured at the weir and removed from the river in an unspawned condition. On the other hand, it was observed that swimming activity of these large active fish also disturbed the substrate. In addition, later runs of undetermined size into the experimental section resulted in continued disturbance of the bottom into November.

The coho spawned extensively in the experimental section, and viable eggs were obtained from several redds during the winter. Personal observations during the collection of the December samples revealed a mass disruption of the substrate. The gravel had the appearance of being freshly washed and seemed to be completely devoid of periphyton. Little, if any, of the gravel escaped disturbance.

Coincident with this mass disruption of the substrate in the fall of 1967, the densities of 12 taxa, as well as the total number and the total weight of organisms decreased significantly (Table 3 ). The significant difference in mean density per square foot between the experimental section and the mean for the two controls was 270.5 (409.5 control minus 139.0 experimental) for total number, and $1.97 \mathrm{~g}$ ( 2.50 control minus 0.53 experimental) for total weight. This is a percent decrease in the experimental section relative to the controls of $66 \%$ for the total number and $78 \%$ for total weight. The difference in density for individual taxa ranged from 51.50 for Hydropsyche, to 0.38 for Brachycentrus americanus (Table 3, Figure 1).

In May 1968, the mean total number of organisms per square foot was still signifi- 

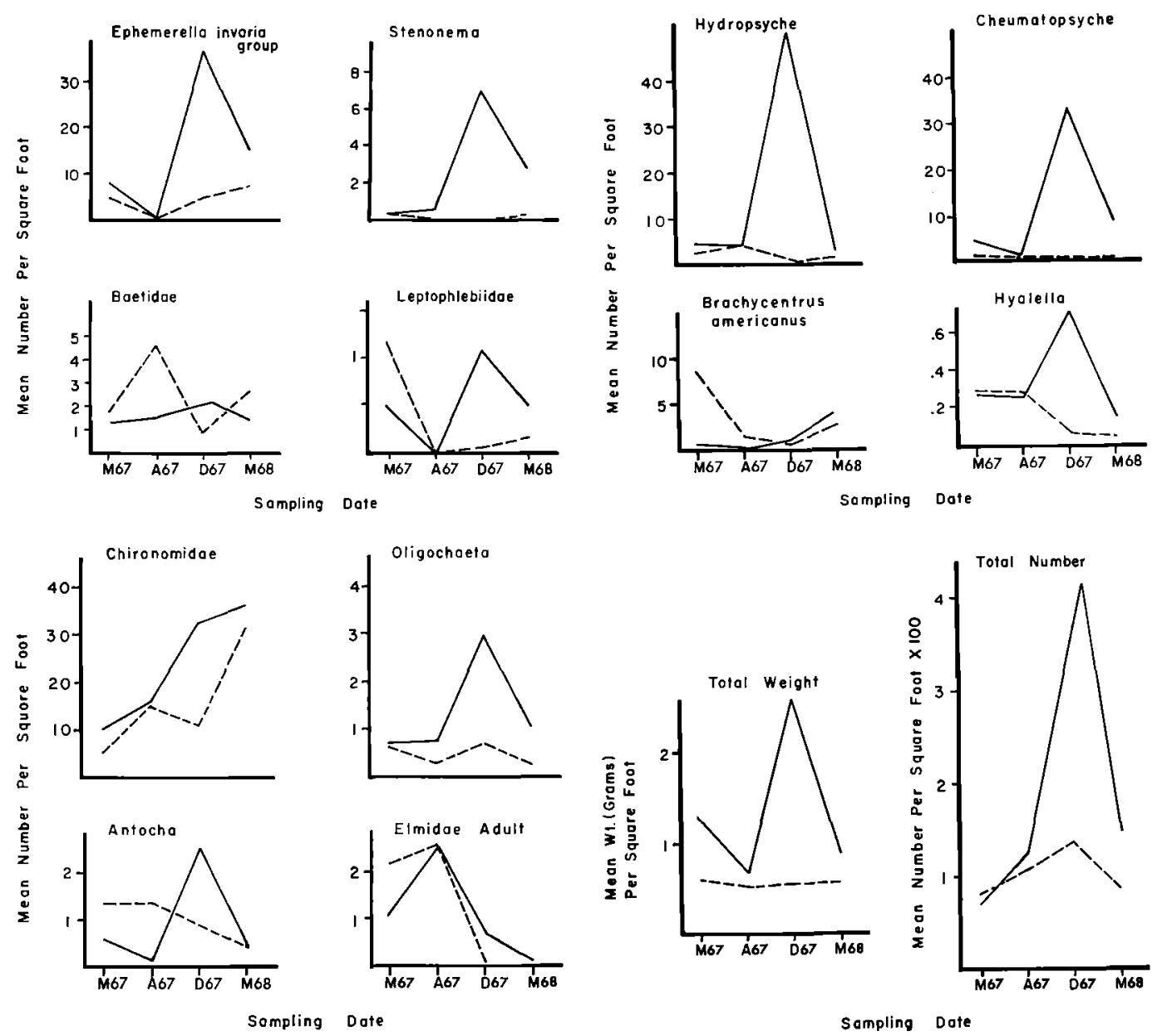

Figure 1.-Densities during the four sampling periods (M67 = May 1967, A67 = August 1967, D67 = December 1967, M68 = May 1968) of taxa affected by salmon spawning. The solid line is the mean for the two control sections. The broken line is the mean for the experimental section.

cantly lower in the experimental section as compared to the controls, but total weight was not significantly lower. Three of the twelve taxa (Stenonema, Leptophlebiidae, and Brachy. centrus americanus) whose density in the experimental section was lower than in the controls in the fall of 1967, were still lower in May 1968 (Table 4). Hexatoma was not significantly affected in the fall by salmon spawning, but its density was significantly lower in the experimental section in May 1968 (Table 4). The difference in mean density for total number of all species between the experimental section and the controls in May 1968 was 57.40 (147.0 control minus 89.6 experi- mental). This is a percent decrease in the experimental relative to the controls of $39 \%$. The mean density difference ranged from 2.88 for Stenonema to 0.32 for Leptophlebiidae (Table 4, Figure 1).

Two critical assumptions were made in this study. The first was that all factors affecting the density of benthic invertebrates were the same in the experimental and control sections except for the presence of spawning salmon in the experimental section. Sprules (1947) states that the most fundamental factors that determine the distribution of stream insects are temperature, nature and configuration of the bottom particles, and flow rate. Qualitative 
TABLE 5.-Taxa affected and not affected by fall salmon spawning activity in the fall of 1967, and categorization as to common, rare, and possession of a heavy case

\begin{tabular}{|c|c|c|c|c|c|c|c|}
\hline \multirow[b]{2}{*}{ Taxa } & \multicolumn{3}{|c|}{ Affected } & \multirow[b]{2}{*}{ Taxa } & \multicolumn{3}{|c|}{ Not affected } \\
\hline & Common & Rare & Case & & Common & Rare & Case \\
\hline $\begin{array}{l}\text { Ephemerella invaria group } \\
\text { Baetidae } \\
\text { Stenonema } \\
\text { Leptophlebiidae } \\
\text { Hydropsyche } \\
\text { Cheumatopsyche } \\
\text { Brachycentrus americanus } \\
\text { Chironomidae } \\
\text { Antocha } \\
\text { Elmidae adult } \\
\text { Hyalella } \\
\text { Oligochaeta }\end{array}$ & $\begin{array}{l}x \\
x \\
x \\
x \\
x \\
x \\
x \\
x \\
x \\
x \\
x \\
x\end{array}$ & & & $\begin{array}{l}\text { Ephemerella needhami } \\
\text { Tricorythodes } \\
\text { Paragnetina } \\
\text { Isoperla } \\
\text { Taeniopteryx } \\
\text { Glossosoma } \\
\text { Trentonius } \\
\text { Atherix variegata } \\
\text { Simuliidae } \\
\text { Hexatoma } \\
\text { Tabanidae } \\
\text { Elmidae larvae } \\
\text { Gammarus } \\
\text { Nematoda } \\
\text { Asellus } \\
\text { Hirudinea }\end{array}$ & $\begin{array}{l}x \\
x \\
x \\
x \\
x \\
x\end{array}$ & $\begin{array}{l}x \\
x \\
x \\
x \\
x \\
x\end{array}$ & $x$ \\
\hline
\end{tabular}

inspection of the gravel substrate in the three stream sections revealed no noticeable difference in nature or configuration, except in the experimental section after salmon were present. The average flow rate over the May 1967 sampling sites was calculated to be 1.67 feet per second in the experimental section, and 1.31 feet per second in the control sections. Water temperature measurements taken at comparable times in the three stream sections did not vary by more than $5 \mathrm{~F}$ of each other. There appeared to be no downstream increase in temperature in the three stream sections. No major natural disturbances of the substrate, such as floods or ice scouring, were observed during the year covered by this study.

The outflow from the trout ponds of the state rearing station entered the upstream end of the experimental section. This may have added some organic matter to this section, but the effects of such enrichment on the benthos was not known.

Another factor that might affect the density of benthic invertebrates in the three stream sections is predation by fish. The estimated numbers of brown trout and rainbow trout in the fall of 1967 were 5,572 in the upper control section, 3,510 in the lower control section, and 4,892 in the experimental section (Taube, unpublished data). Since the areas of the three stream sections are nearly the same (Table 1), these figures suggest that predation pressure on the benthos in the experimental section was intermediate between the control sections prior to the spawning run of salmon in the fall of 1967. On the basis of the above information, I consider the first assumption valid.

The second assumption invoked was that the spawning salmon were not feeding on benthos of the experimental section. An analysis of stomachs from adults at the weir at the upstream end of the experimental section, and conversations with fishermen, who had examined salmon caught in the river, support this assumption (Taube, unpublished data).

Of the 28 taxa tested for the effect of salmon spawning, the density of 12 was significantly reduced in the fall of 1967 (Table 3). Sixteen taxa were not affected. Two major reasons are postulated to account for a taxon not being affected by salmon spawning. First, if a taxon is rare, the probability of detecting such an effect using the methods employed in this study is low. Second, if a taxon has a heavy stone case and is disturbed by digging activity, it would settle back to the bottom instead of being swept away by the current. If a taxon is common, and does not have a heavy case, it should be affected by salmon spawning activity. I define rare as a mean density of less than 0.50 individual per square foot for the two control sections in December 1967. Common is defined as having a mean density of greater than 0.50 individual per square foot for the two control sections in December 1967. These criteria account for 11 taxa not being affected in the fall by salmon spawning activity, but they do not explain why 5 taxa 
in the common category were not affected (Table 5). The explanation for these taxa not being affected probably lies in some behavioral trait of the individual taxa. The 12 taxa that were affected by salmon spawning activity were in the common category. In the case of Glossosoma, a common organism which has a case, the possession of a case is believed to be the reason that this taxon was not affected.

It has been demonstrated that coho spawning activity decreased the density of the common benthic invertebrates in the experimental section in the fall. The samples for May 1968, show that all but three of these taxa had recovered so as to be comparable with control levels (Tables 3 and 4). The total number of individuals per square foot in the experimental section in May 1968, was still significantly less than the controls, but this difference $(57.40)$ was less than one-fourth the difference observed in December (270.50).

Hexatoma did not appear to be affected by spawning salmon in the fall, but its density was significantly lower in the experimental section in May 1968 (Table 4). The explanation of this unexpected finding is not apparent.

In a period of 5 months (December-May), $75 \%$ of the taxa affected by salmon spawning activity had recovered to control levels. Total number of individuals per square foot had not recovered completely. The time involved for a stream substrate denuded of benthic organisms to recover to normal densities has been estimated to be from 3 months (Moffett, 1936; Kennedy, 1955) to a day or two (Waters, 1964). Downstream drift of benthos from undisturbed upstream areas appears to be a mechanism sufficient to return disturbed populations to normal levels in a short time (Waters, 1964). Accepting drift as the mechanism of recolonization, it appears that drift from control sections in the Platte River was insufficient to completely recolonize the experimental section in 5 months following the coho spawning in the fall of 1967.

The importance of the observed decrease in benthos in the experimental section to the total benthic resource of the river, and to the food intake and growth of resident trout cannot be completely assessed from the results of this study. If one assumes that the organisms disturbed by salmon were destroyed in some manner by spawning activity, there would have been an immediate loss of benthic food organisms from the system. In a period of 5 months, drift from upstream areas did not completely replace this loss. The importance of this loss to the feeding and growth of native trout in the river depends upon how long the disturbed area contains a reduced amount of benthic food, and upon the magnitude of this loss as compared to normal production of drift and benthos in the river. In Michigan, brook trout exhibit most active growth in the period May through October (Cooper, 1953). If this time of most rapid growth can be projected as applicable to brown and rainbow trout, then this would be the time when benthic invertebrates would be maximally utilized as food. The decrease in benthos in the fall occurred at a time when trout may not have been feeding actively. In May 1968, in the experimental section, recovery of benthos was not complete. Trout beginning to feed at this time would have less food available than if salmon had not disturbed the benthos. It was not determined in this study whether the magnitude of difference in total benthic density (57.4 per square foot) in the experimental section in May 1968 , was significant compared to the normal production of drift and benthos in the river, or whether the difference would affect the growth of trout.

The observations of Waters (1962 and 1964), suggest that drift rates of Baetis vagans and Gammarus pseudolimnaeus are lowest in the period December-February, begin to rise in March, peak in August, and begin to fall in October. If we accept this as the general seasonal trend for total drift, and drift as the mechanism of recolonization, rate of recolonization might follow the same seasonal trend. In the Platte River, complete recovery of the benthos was not observed in the period December-May. Recolonization rates however would be low during this period. It seems reasonable to expect complete recovery of the benthic population by mid-summer if re- 
colonization rates are increasing. If the above mentioned time schedules are accurate, native trout in the Platte, occupying an area disturbed by salmon spawning, would be exposed to a lower than normal amount of available benthic food for 2 or 3 months of their 6 months of active feeding. Future research might reveal how important this reduced level of benthic food is to the growth of trout.

Successful spawning of coho salmon in the Platte River resulting in recruitment of stream resident salmon may result in an increased demand on the benthos as a source of food. Ruggles (1959) reports that in the Wenatchee River, Washington, a tenfold increase in salmon populations resulted in a decrease in bottom fauna to nearly one-fifth normal levels. $\mathrm{He}$ attributes this reduction in benthos to the grazing activity of the increased numbers of young salmon. In the Platte River, if there is extensive recruitment of young coho salmon, this added predation pressure on the benthos coupled with a reduction in benthos density due to coho spawning activity, might reduce the benthic populations to the extent where growth of native trout and salmon may be limited.

\section{ACKNOWLEDGMENTS}

This research was supported by the Institute for Fisheries Research, Michigan Department of Natural Resources, and a faculty grant from the Horace H. Rackham School of Graduate Studies of The University of Michigan. James T. McFadden, Frank F. Hooper, and William C. Latta reviewed the manuscript. James R.
Ryckman helped with the statistical analysis. Clarence M. Taube provided information on the fish populations.

\section{LITERATURE CITED}

Anderson, Richard O. 1959. A modified flotation technique for sorting bottom fauna samples. Limnol. Oceanogr. 4(2) : 223-225.

Burner, Cijfford J. 1951. Characteristics of spawning nests of Columbia River salmon. U.S. Fish Wildl. Serv. Fish Bull. 61: 97-110.

Cooper, Edwin L. 1953. Periodicity of growth and change of condition of brook trout (Salvelinus fontinalis) in three Michigan trout streams. Copeia, 1953(2) : 107-114.

Kennedy, Harry D. 1955. Colonization of a previously barren stream section by aquatic invertebrates and trout. Prog. Fish-Cult. 17(3): $119-122$.

Moffett, JAmes W. 1936. A quantitative study of the bottom fauna in some Utah streams variously affected by erosion. Bull. University of Utah, Biol. Ser. 3(3): 1-32.

Ruggles, C. P. 1959. Salmon populations and bottom fauna in the Wenatchee River, Washington. Trans. Amer. Fish. Soc. 88(3) : 186-190.

Shapovalov, Leo, and A. C. Taft. 1954. The life histories of the steelhead trout (Salmo gairdneri gairdneri) and silver salmon (Oncorhynchus kisutch) with special reference to Waddell Creek, California, and recommendations regarding their management. California Dept. Fish Game, Fish Bull. 98: 1-375.

Sprules, W. M. 1947. An ecological study of stream insects in Algonquin Park, Ontario. Univ. Toronto Studies, Biol. Ser. 56: 1-81.

Steel, R. G. D., and J. H. Torrie. 1960. Principles and Procedures of Statistics. McGraw-Hill Co., Inc., New York. 481 pp.

Waters, Thomas F. 1962. Diumal periodicity in the drift of stream invertebrates. Ecology $43(2)$ : $316-320$.

_. 1964. Recolonization of denuded stream bottom areas by drift. Trans. Amer. Fish. Soc. 93(3): 311-315.

-_ AND RoBert J. KNaPP. 1961. An improved stream bottom fauna sampler. Trans. Amer. Fish. Soc. 90(2) : 225-226. 